\title{
Parental Influence on Children's Self- esteem and Academic Performance among Secondary School Students in Two Counties in Kenya
}

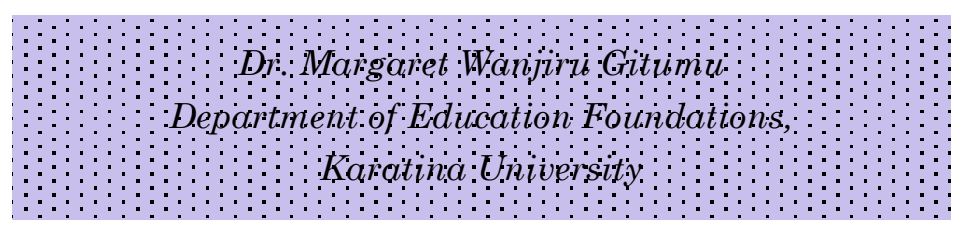

\section{Abstract}

The environment in which a child is brought up is likely to influence the level of self-esteem of the child. As such, the death of parents that results in orphanhood may have setbacks on the development of self-esteem of orphans. Self-esteem is central to high academic performance and this is a key factor for development in any nation. The self-esteem of students may have influence on academic work since the students with high self-esteem are said to perform highly academically. The purpose of this study was to find out whether there is significant difference in self-esteem levels of orphans and non orphans in Kirinyaga and Nyeri Counties, Kenya.

This study was guided by Bowlby's theory of attachment. The study adopted a survey, which utilized casual comparative research design. According to the 
education offices in the two counties, the total population of students was 58,448 Simple random and purposive sampling methods were used to obtain the sample which was 400 students. The data was collected using a questionnaire. Data was analyzed using descriptive and inferential statistics. The major finding in this study was that the orphans registered lower level of self-esteem than non orphans. The study recommends that orphans should be incorporated into comprehensive child protection policies and programmes that would enlighten the caregivers on requirements for psychological development to ensure development of high self-esteem which would translate to high academic performance and high national development.

\section{Introduction}

\section{Parental Influence on Children's Self-esteem}

Parenting is the process of promoting and supporting the physical, emotional, social, and intellectual development of a child from infancy to adulthood (Wikipedia, 2013). Parents can therefore be said to have great influence on children during childhood. Bornstein (1988) observed that childhood is the phase of the life cycle when parents provide experiences that are believed to exert significant influences. 
This is so because the parents' attitudes, feelings and actions are always recorded in the child's mind and form a basis of the child's selfimage. Indeed, Dehert, Sroute and Cooper (2000) observe that children are born with inherited tendency to seek social stimulation and to form strong attachment to parents or caregivers.

The attachment bond is the unique emotional relationship between the baby and the parent as his or her primary caretaker. The attachment bond is a key factor in the way your infant's brain organizes itself and influences the child's social, emotional, intellectual, and physical development (Robinson, Saisan, Smith \& Segal, 2012). The forming of attachment is considered to be the foundation of the infant/child's capacity to form and conduct relationships throughout life. Attachment is not the same as love and/or affection although they often go together. Attachments develop immediately and a lack of attachment or a seriously disrupted capacity for attachment could seriously damage a child's health and well-being. Physically, one may not see symptoms or indications of a disorder but emotionally the child may be affected. Studies show that children with secure attachment have the ability to form successful relationships, express 
themselves on an interpersonal basis and have higher self-esteem. Conversely, children who have caregivers who are neglectful or emotionally unavailable can exhibit behavioral problems such as post-traumatic stress disorder or oppositionaldefiant disorder.

It has been suggested that the level of selfesteem is a product of the extent to which the child was praised, encouraged or relentlessly criticized (Rainey \& Rainey, 1986). Moreover, stability of the mother-father relationship either creates in children a sense of security or insecurity. The children who are emotionally secure tend to exhibit high self -esteem. The parents who withhold unconditional love and acceptance create a child who must perform to be accepted and looks to others for the missing approval.

According to Newman (1993), parents impact on the child's self-esteem because any negative communication lowers the child's self-esteem. Those children who have experienced a lot of love and fair discipline have high self-esteem. They accept who they are because they have been accepted as cherished beings by the parents. Conversely, children who have been pushed around, ignored, 
physically abused, live in uncertainty and fear. Those children who are separated from their parents for long periods develop a low self-esteem. Parents who are over permissive, over protective or label their children as 'stupid dummies' who cannot do anything right make their children develop low self-esteem.

Orphan hood is widely viewed as a circumstance which causes not only grief and psychological trauma, but also anti-social behaviour in children. Gen (2002) in Potts (2006) observed that orphaned children have traditionally been cared for within the extended family, often by elderly grandparents. Moreover, Kelly (2006) asserts that the rise in orphan hood is overwhelming the ability of families, communities, civil societies, and governments should help the orphans.

Self-esteem has been referred to as the survival of the soul as it is the ingredient that gives dignity to human existence. It grows out of human interaction in which the self is considered important to someone (Rice, 1984). As such, it has been observed that human infants form an emotional attachment to their primary caretakers (usually the parents) and there is a critical period during 
which this must occur for healthy development (Coon, 1986). In the same vein, Dehert, Sroute and Cooper (2000) observe that children are born with inherited tendency to seek social stimulation and to form strong attachment to caregivers. Moreover, Weiner (1992) suggests that the association between internal ascriptions for outcomes and selfesteem is an integral part of everyday interactions. These interactions may be through words, visual or through actions. According to Morris (1991) babies hear before they are born. He observes that: "The last two or three months of womb-life, the growing baby is already a listening baby, hearing the rhythmic sounds of its mothers body and even relating to noises from the outside world" (p. 54). Similarly, babies can hear the words of praise which are soothing. In addition, Seifart and Hoffnung (1991) contend that infants can organize the sounds they hear and can hear as well as perceive what they hear. They observe that two day old infants can locate sounds. If the sounds are not soothing, the infants cry indicating distress and a threat to the ego development.

A new born baby is perfectly attuned to focus, his/her eyes and to concentrate them on the object in front of his/her face (Morris, 1991). Moris 
further argues that as soon as the baby and mother recover from the trauma of delivery, they spend up to an hour starring intently at each other if given a chance before falling asleep. This mutual gazing at close quarters starts to form a bond of attachment right from the first moment. Moreover, Seifert and Hoffnung (1991) suggest that two days old new borns, discriminate between human faces and abstract patterns and they look at faces longer than at eight patterned disks.

Self-esteem of children is a very central issue because it has direct impact on the child's performance in schoolwork (Krider, 2002). This is because low self-esteem negatively affects learning while high selfesteem enhances it. In addition, Braden (2002) in Vurughase (2003) describes self-esteem as the one common denominator in all neurotic problems. Selfesteem is also the foundation of personal growth, learning, creativity, personal accountability and responsibility and personal relations. A child's selfesteem determines the degree to which he/she may maximize the resources and tools he/she was born with (Wolner, 2010). According to Baumeister (2009), high self-esteem might improve performance by increasing one's confidence, by making people persist despite initial failure, by means of self-fulfilling prophecies and by eagerness to seek out challenges. 


\section{Objective of the Study}

The study sought to determine whether there are any differences in self-esteem level between students who are non orphans and total orphans.

\section{Theoretical Framework}

This study was guided by the Attachment theory by Bowlby (1969). This theory was developed by Bowlby (1969) and later adopted by Ainsworth (1979) in Santrock (1981). Bowlby (1969) and Ainsworth (1979) argue that the first attachment begins at birth and is usually fully cemented within several years after birth. They observed that babies form long-term emotional attachment to their parents especially their primary caregivers usually the mothers. Bowlby (1969) in Sternberk (1998) contends that an infant's attachment pattern has longterm effects on the child's development. Bowlby gives two forms of attachment that is secure and insecure attachment.

Secure attachment is positive bond that de-

velops between the infant and the caregiver. The bond is believed to promote healthy exploration of the world because the caregiver provides a secure 
base to which the infant can return if stress is encountered. Bowlby (1969) and Ainsworth (1979) in Santrock (1981) argue that secure attachment in infancy is central to the development of social competence.

Insecure attachment is the relationship between the infant and the caregiver in which the infant avoids the caregiver. Bowlby (1969) in Santrock (1981) asserts that insecure mother-infant attachment results in a lack of love and affection in childhood which creates a negative cognitive set. From Bowlby's view, early experiences, especially those involving loss, produce a cognitive scheme that is carried forward to influence the way later experiences are interpreted. When these new experiences involve further loss, the loss serves as the immediate precipitant of depression. This theory guides this study because students from families with both parents alive may enjoy secure attachment while the orphan students may find themselves in insecure attachment. 


\section{Methodology}

Research Design

The research design adopted by this study was survey, which employed casual-comparative approach. This study design was found suitable for this study since the phenomenon under investigation was already in existence. This research design used questionnaires or interview schedule to collect data from participants in a sample about their characteristics, options, and experiences, in order to generalize to the population (Gall, Borg \& Gall, 1996). This design therefore suited this study as the study set to get opinions and attitudes of orphans andnon orphan students. The study was carried out in Nyeri and Kirinyaga Counties, Kenya

\section{Target Population}

The study targeted male and female form one to form four students enrolled in public secondary schools in Nyeri and Kirinyaga Counties, Kenya. 


\section{Sampling Technique and Sample Size}

The schools were stratified into two categories as provincial schools and district schools. Additionally, the schools were sampled by type that is, girls' schools, boys' schools and mixed schools. The total population of students in the registered public secondary schools in Nyeri and Kirinyaga Counties was 58,448 . The sampling techniques used in this study included purposive, used to sample the schools and the orphans. The schools were purposively sampled according to the high number of orphans registered in education offices in Nyeri and Kirinyaga Counties. The researcher purposively selected 11 secondary schools (provincial and district) to participate in the study. The orphans were also purposively selected by use of class registers. Students from two parent families were sampledusing simple random sampling. The sample size was 400 students. A questionnaire with two sections: section one to collect personal data while section two to collect data on self-esteem adopted from Barksdale Foundation (2002) was used. Descriptive

and inferential statistics were used to analyze the data. 


\section{Findings}

The study sought to find out whether there are any statistical significant differences in selfesteem level between orphans and non orphans students. To investigate this, the hypothesis stated that there was no statistically significant difference in self-esteem level between orphans and non orphan students. The study also sought to find out the mean of self-esteem levels of orphans and non orphan students and the findings indicated that most orphans registered low self-esteem mean (69\%) while the orphans with moderate self-esteem mean were $28 \%$. However, $1.8 \%$ of the orphans registered high self-esteem. This may be explained by the fact that orphans live in different environments which may influence the development of their selfesteem differently. The highest percentage of nonorphan students registered moderate level of selfesteem mean (47\%) while $17 \%$ of the non orphan students registered low self-esteem. The $36 \%$ of non orphans registered high self-esteem. This scenario may be explained by the fact that not all non orphans live in an environment that influence their self-esteem positively. There may be some parents who might mistreat their children impacting negatively on their ego development leading to develop- 
ment of low self-esteem. Table 1 shows the selfesteem levels of orphans and non orphans as explained.

Table 1: Distribution of Students by their Status and Self-Esteem level

\begin{tabular}{llcc}
\hline C & $\begin{array}{l}\text { Self- } \\
\text { esteem } \\
\text { level }\end{array}$ & $\begin{array}{c}\text { Fre- } \\
\text { quency } \\
\text { (f) }\end{array}$ & $\begin{array}{c}\text { Percentage } \\
\text { (\%) }\end{array}$ \\
\hline Orphans & Low & 118 & 69.4 \\
& Moderate & 49 & 28.8 \\
& High & 3 & 1.8 \\
& Total & 170 & 100.0 \\
& Low Orphans & 39 & 17.0 \\
& Moderate & 108 & 47.0 \\
& High & 83 & 36.0 \\
& Total & 230 & 100.0 \\
\hline
\end{tabular}

To bring out the impact of self-esteem on education performance, the education aspirations of students were analyzed and the findings were that the students who did not aspire for higher educational level registered a low self-esteem mean. In the same way, the students who aspired to attaining a degree and post graduate level of education recorded a higher self-esteem mean. This information is indicated in Table 2 
Table 2: Self-Esteem Mean of Students by Educational Aspiration

\begin{tabular}{|l|c|c|}
\hline $\begin{array}{l}\text { Aspired educa- } \\
\text { tional level }\end{array}$ & $\begin{array}{c}\text { Fre- } \\
\text { quency (f) }\end{array}$ & $\begin{array}{l}\text { Mean of self-esteem } \\
(\bar{x})\end{array}$ \\
\hline Form four & 8 & 46.13 \\
\hline Certificate & 24 & 49.21 \\
\hline Diploma & 29 & 59.28 \\
\hline Degree & 202 & 66.25 \\
\hline Post Graduate & 137 & 60.50 \\
\hline
\end{tabular}

These findings are in agreement with Adams and Gullotta (1989) who observed that high academic ability and performance were both predictors of high self-esteem.

Moreover, Rice (2006) argues that people with high self-esteem consider it important to succeed, but those with low self-esteem are less likely to expect they will succeed. He further points out that children who aspire upward mobility also have a strong sense of self-esteem, whereas children with downward mobility indicate self-rejection. It can therefore be said that with high self-esteem, students aspire high level of education and vise versa is also true. 
The t-test was ran for the two groups of orphans and non orphans and the findings were that there was a difference in self-esteem between the two groups which was significant $(\mathrm{t}=-6.243, \mathrm{P}<$ $0.05)$.

\section{Discussion}

The research question stated: Are there any differences in self-esteem level between orphans and non orphans? The hypothesis stated: there are no statistically significant differences in self-esteem level between orphans and non orphans. The results indicated that there was statistically significant difference in self-esteem level between orphans and non orphans $(t=-6.243, \mathrm{p}<0.05)$. Therefore, Ho suggesting that there was no statistically significant difference in self-esteem levels between orphans and non orphan students was rejected. This difference could be attributed to a number of factors as portrayed by the theory guiding this study.

As such, the results of this study are in agreement with the theory of attachment by Bowl (1969); the development of secure attachment is very important in the development of self-esteem. 
Secure attachment is a bond that promotes healthy exploration of the world to which infants return to if they encounter stress. In the view of this, it is then possible that the orphans under study may not have developed secure attachment and instead developed insecure attachment reflecting a lack of love and affection in childhood and this creates a negative cognitive set.

This probably might be the reason as to why orphan students registered a lower mean of selfesteem than the non orphan students. These results indicate that parents perhaps contribute to the development of self-esteem as the primary care takers of the children to which some of the orphans had not had a chance especially if their parents died in early childhood.

According to Sarafino and Armstrong (1986) secure attachment thrives when parents are affectionate, caring and sensitive to the baby's needs. In such a case, it might mean that orphans may not have had a chance to develop secure attachment pointing to low self-esteem. In addition, Steinberg (1999) put forward that parents influence their children's self-esteem through the genes they pass on as well as through the environment they provide. Indeed, scholars have indicated the impor- 
tance of the two parents in the development of selfesteem. Also, Seifart and Hoffnung (1991) point out that parents' interaction with their children sensitively and appropriately help in development of secure attachment relationship leading to early emergence of a strong sense of self-esteem. As such, it is possible that the non orphan students developed secure attachment with their parents while the orphans may have failed to develop the bond between their parents especially if the parents died when the orphans were young.

\section{Conclusion}

In conclusion, orphan students registered low self-esteem in comparison to non orphan students. It is important to note that orphans are among the future generation of the Kenyan society that should bring development. However, faced with minimum opportunities to alleviate poverty, food insecurity and inhuman suffering which affect negatively their self-esteem and result to low academic performance thus poor development. 


\section{Recommendation}

Orphans registered a low self-esteem probably due to lack of secure attachment more so if the parents died while the children were young. Therefore, orphans should be incorporated into comprehensive child protection policies and programmes that would enlighten the caregivers on requirements for psychological development to ensure development of high self-esteem which would translate to high academic performance and higher national development. Government officers should assess orphanages to establish the conditions orphans are put in by the managers of children's homes. This can be done at the national and local levels. 


\section{References}

Adams, G. R., \& Gullotta, T. (1989). Adolescent life experience (2nd ed.). In Ahamed, N. A., Quhar, J., Siddiq, A., Maseed, A. Rasheed, J., Jabar, F., \& Knorring, A. C. (2004). A 2- Year follow-up of orphans competence, socio emotional problems and post traumatic stress symptoms in traditional foster care and orphanages in Iraqi Kurdistan. Retrieved June 7, 2006, from http:// www.blackwell-synergy.com/links/do//10.uu/ j.1365-2214.2004.00477.x/abs

Amstrong, J. W., \& Sarafino, P. S. (1986). Child and adolescent development (2nd ed.). New York: West Publishing Company.

Barksdale, L. S. (2002). Self-esteem test. Retrieved March 12, 2004 from http://www.barksdale.org.

Baumeister R. (2009.) Self-esteem. Retrieved March 22, 2013, from http://www.education.com/reference/ article/self-esteem2/

Bornstein, M. H. (1989). Parents. Retrieved November 16, 2006 from http://parenthood. Library edu/ Bornstein/Bornstein.html.

Coon, D. (1986). Introduction to psychology: Exploration and application (4th ed.). New York: West Publishing Company. 
Dehert, G. B., Sroute, L. A., \& Cooper, R. G. (2000). Child development. Its nature and course (4th ed.). New York: McGraw-Hill Companies Inc.

District Education Officers. (2006). Student's enrolment. Nyeri and Kirinyaga: District Education Offices.

Kelly, H. (2006). Orphanhood, poverty and HIV risk behaviour among youth population in Kwa Zulu Natal, South Africa. Retrieved March 2, 2007, from HTML paa 2006.princeton.edu/ download.aspx? Submissiononld $=61795$.

Morris, D. (1991). Baby watching. New York: Crown Publishers Inc.

Newman, F. (1993). Children in crisis. Toronto: Scholastic Canada Ltd.

Potts, A. (2006). Socio-economic status and HIV/AIDS in sub-Saharan Africa. Retrieved August 27, 2006, from http://www.bsh.utah.edu/modules.Php? o $\mathrm{p}=\mathrm{m}$ a $\mathrm{d} l$ o $\mathrm{a}$ d \& $\mathrm{n}$ a $\mathrm{m}$ e = News\&file $=$ article\&sid $=6$ socio-economic status and HIV/AIDS in sub-saharanafrican

Rainey, other name? \& Rainey, A. (1986). Building your mates, self-esteem. City? Here's Life Publishing Inc.

Rice, F. P. (1984). The adolescent. Development relationships and culture (4th ed.). Boston: Allyn and Bacon Inc. 
Robinson, L., Saisan, J., Smith, M., \& Segal, J. (2012). Building a secure attachment bond with your baby. Retrieved March 22, 2013, from http:// www.helpguide. Org/mental/parenting attachment.htm.

Santrock, J. W. (1981). Adolescence (4th ed.) Dallas, Texas: WMC Brown Publishers.

Seifart, K. L. \& Hoffnung R. J. (1991). Child and adolescent development (2nd ed.). Boston: Houghton Mifflin Company.

Steinberg, L. (1999). Adolescence (5th ed.). Boston: McGraw-Hill Company.

Sternberg, R. J. (1998). In search of the human mind. (2nd ed.). New York: Harcourt Brace \& Company.

Vurughese, S. (2003). Your esteemed self. Retrieved November 16, 2006, from http:// www.alifepositive.com/mind/persoanal-growth/ self/love/esteem.esp.

Weiner, B. (1992). Human motivation: Metaphors, theories and research. Newbury Park: Sage Publications Inc. 